\title{
The Analysis of Meat Market Situation and Reproduction Process in Terms of Food Security
}

\author{
Vrublevskaya V.V.* \\ Irkutsk State Agricultural University named after \\ A.A. Ezhevsky \\ Irkutsk, Russia \\ e-mail v.v.v.3650@mail.ru
}

\author{
Mamaeva A.I. \\ Irkutsk State Agricultural University named after \\ A.A. Ezhevsky \\ Irkutsk, Russia \\ e-mail tera2805@mail.ru
}

\begin{abstract}
The reproduction process in agriculture is closely associated with the agro-food market and the country's food security. The determination of the reproduction process type allows establishing recommendations for stimulating the core drivers of the agro-food market and increasing the level of food security. In turn, the development of the agro-food market and the level of food security determine the development of the reproductions process.
\end{abstract}

Keywords - reproduction process, provision, market, agriculture, analysis, assessment, meat, Russia.

\section{INTRODUCTION}

Agricultural production is a continuous and repeating process. People need food and this demand is ever-growing. This production is the basis for further consumption. In turn, consumption is the major driver of production. Thus, production and consumption processes are closely interrelated and complement each other [7].

Providing quality food for the population is one of the most important tasks of the state. The government can solve it by implementing an extensive process of reproduction and food market development.

An extensive reproduction process should establish a stable supply in the market and provide the population with its own products, thus ensuring the food security of the country.

\section{METHODS AND MATERIALS}

Modern literature addresses reproduction processes in agriculture in separation from the agro-food market. Our research aims to determine the type of the reproduction process considering the current situation in the meat market. This is necessary to assess food security in Russia in terms of meat products and develop recommendations for its promotion.

The research involved a proprietary methodology for determining the reproduction process and the methodology for assessing the level of food security in terms of meat products based on supply and demand in the market. We used official statistics data both at a federal and regional level as well as report data of several agricultural organisations

Based on the results we conclude that an extensive type of reproduction process has established in Russia. An increased meat production ensures meat self-sufficiency which in turn raises the demand in the meat market. At the same time the import is decreasing, and the level of food security is growing.

The further increase in the level of food security is possible with keeping an extensive type of the reproduction process This allows increasing both the production and export of meat to other countries, including China.

Meat is in high demand around the world. In Russia, the alimentary tradition supposes, as a rule, the presence of meat almost in any dish. It is also one of the main sources of protein

The Russian meat market is one of the largest sectors of the food market. It is characterised by high capacity and stable demand. The market is experiencing globalisation, its major players are becoming larger, increasing the amount of production, and improving technologies [3]

Today, the most perspective and effective agricultural enterprises are those that implement a full cycle of producing and selling their products. Thus, highly integrated producers which completely process meat using advanced technologies have an opportunity to increase the level of production and decrease their expenses within the food chain.

An extensive reproduction process demands profit, first of all. Only profitable enterprises can increase their production. Thus, an intensive increase in production scope, integration, and the decrease of expenses are necessary for extensive reproduction.

This type of reproduction helps to achieve a necessary level of food security almost for every type of food product in the country. Food security represents both physical (volume and quality) and economic availability of food for people, i.e. the level of food provision for the population. A necessary level of provision is achieved, first of all, by a sufficient production of quality food both within the country and a separate region.

To analyse the level of meat provision we used the following indicators:

1. the volume of meat production measured in carcass weight and taken by categories of households in natural units - comparing this indicator in dynamics will help to determine the type of the reproduction process without covert factors (inflation, etc.). 
2. Self-sufficiency measured in percentage and calculated based on production and consumption of meat per one person/year - shows the availability of the own-produced meat for people.

3. The ratio of meat and meat products import and export - shows the level of food security in terms of this category of products.

Food security encompasses all stages of the reproduction process, including production, distribution, exchange, and consumption [1]. Thus, reproduction, self-sufficiency, and the level of food security are the categories which should be considered, analysed, and assessed jointly. Our methodology helps to do it.

We calculated the described indicators based on statistics. This helped us to determine both the type of reproduction and the level of self-sufficiency as well as see the opportunities for increasing the volume of production and the saturation of the market. As a result, we were able to give the recommendations and predictions for its development.

This methodology is suitable both for the country as a whole and for separate regions. It uses standard data available in the statistical form and encompasses all the necessary issues of food security: the level of production, whether this level is enough, and the level of food security.

We considered the reproduction of meet in terms of meat types (pork, beef, chicken, etc.), first of all. At the country level, it is also necessary to consider the categories of main producers. To determine the type of reproduction without covert factors it is necessary to compare both the volumes of production by years in natural units: kilograms, centners, and tonnes.

The main types of meat produced in Russia are poultry meat (chicken, turkey, etc.), pork, cattle meat (veal, beef), mutton, rabbit meat, and other types (table 1).

TABLE I. THE PRODUCTION OF CATTLE AND POULTRY BE CARCASS WEIGHT AND THE CATEGORY OF THE HOUSEHOLD FOR 2000-2018.

\begin{tabular}{|c|c|c|c|c|c|}
\hline \multirow[b]{2}{*}{ Indicator } & \multirow{2}{*}{\begin{tabular}{|c|}
2000 \\
$\begin{array}{c}\text { Thousand } \\
\text { tonnes }\end{array}$ \\
\end{tabular}} & \multirow{2}{*}{\begin{tabular}{|c|}
2010 \\
$\begin{array}{c}\text { Thousand } \\
\text { tonnes }\end{array}$ \\
\end{tabular}} & \multicolumn{2}{|l|}{2018} & \multirow{2}{*}{$\begin{array}{c}2018 \text { as } \\
\% \text { of } \\
2000\end{array}$} \\
\hline & & & $\begin{array}{c}\text { Thousand } \\
\text { tonnes }\end{array}$ & $\%$ & \\
\hline Agricultural organisations & 1787 & 4342 & 8395 & $\begin{array}{l}79 . \\
1\end{array}$ & 469.8 \\
\hline Private households & 2579 & 2615 & 1912 & $\begin{array}{l}18 . \\
0\end{array}$ & 74.1 \\
\hline \begin{tabular}{|l|} 
Farming households \\
\end{tabular} & 80 & 210 & 305 & 2.9 & 381.3 \\
\hline $\begin{array}{l}\text { Households of all } \\
\text { categories, including }\end{array}$ & 4446 & 7167 & 10612 & $\begin{array}{l}10 \\
0\end{array}$ & 239.1 \\
\hline cattle animals & 1898 & 1727 & 1569 & $\begin{array}{l}14 . \\
8\end{array}$ & 82.7 \\
\hline Pigs & 1578 & 2331 & 3516 & $\begin{array}{l}33 . \\
1\end{array}$ & 222.8 \\
\hline poultry & 768 & 2847 & 4941 & $\begin{array}{l}46 . \\
5\end{array}$ & 643.4 \\
\hline sheep and goats & 140 & 185 & 219 & 2.1 & 156.4 \\
\hline
\end{tabular}

Currently the main types of meat produced in Russia are poultry $(46.5 \%)$ and pork $(33.1 \%)$ due to their early maturation and high profitability. Because of increased net cost and a long period of cattle growing, beef is less profitable, thus accounting only for $14.8 \%$, even that this meat is healthy for eating. The demand for this meat is also decreasing due to an increase in prices.

Overall, we should note an increase in meat production in carcass weight by 2.3 times between 2000-2018 for the whole country. In 2018 the volume of production was 10,612 thousand tonnes. We should especially note the 2.2 times increase in pork production, a $56.4 \%$ increase in sheep and goat meat production, and 6.4 times increase in poultry meat production. The volumes of beef production decreased by $17.3 \%$ and accounted for 1,569 thousand tonnes in 2018 . Also, agricultural organisations and farm households increased the production of cattle and poultry by 4 times in terms of carcass weight. However, private households decreased the level of production by $25.9 \%$ in the period of 2000-2018, but this didn't influence the whole picture. Pig and poultry farming are rapidly developing as they provide faster ROI and have low production costs in comparison to beef. This is proven by the fact that poultry production has increased by 6.4 times for the last 18 years.

However, we should not underestimate the production of beef and mutton, although they are more expensive than pork and, especially, chicken. Keeping these animals needs less electricity thus decreasing the cost of power needed to produce this meet. As the price of electricity is ever-growing, this becomes one of the determining factors in any type of production.

Agricultural organisations are the main meat producers, accounting for $79.1 \%$. Private households produce $18.0 \%$, while farming households yield $2.9 \%$. In meat production one of the main criteria of profitability is the scope of production. For example, pig farming becomes profitable when there are not less than 1000 animals. For private households and small farms, this number is quite big. It is possible to keep such a big number of animals only having particular equipment and facilities. Thus, agricultural organisations are the main producers of meat in Russia. Private households not only decrease the volume of production but also their share in total production. Partially, this happens due to a decrease in the country's population.

We analysed the volume of Russian-produced meat in natural units (thousand tonnes of carcass weight) for 2000 2018 and found that its type of production is extensive.

The assessment of self-sufficiency (table 2) begins with analysing the consumption of meat in kilogrammes per one person/year. This indicator is compared with a recommended norm of food consumption. According to the Russian Ministry of Public Health the recommended norm of meat consumption per one person/year is $73 \mathrm{~kg}$ ( $20 \mathrm{~kg}$ of beef, $3 \mathrm{~kg}$ of mutton, $18 \mathrm{~kg}$ of pork, $31 \mathrm{~kg}$ of poultry and $1 \mathrm{~kg}$ of other types of meat).

Comparing the actual level of meat consumption with a recommended norm we can see that, first of all, there is an increase in consumption by $30.6 \mathrm{~kg}$ between 2000 and 2018 . Secondly, we can see that the norm of consumption was achieved in $2012(75 \mathrm{~kg})$. Assessing the self-sufficiency, we can see that this indicator increased by $32.8 \%$ and accounted 
for $96.8 \%$ in 2018 . Thus, we can say that the country is not fully provided with meat, but the necessary level of food security is achieved. According to the Russian food security doctrine the level of self-sufficiency in terms of meat should not be lower than $85 \%$ [6].

TABLE II. THE SELF-SUFFICIENCY OF MEAT IN RUSSIA FOR 2000-2018

\begin{tabular}{|l|l|l|}
\hline \multicolumn{1}{|c|}{ Years } & \multicolumn{1}{|c|}{$\begin{array}{c}\text { Demand kg/person } \\
\text { per year }\end{array}$} & Self-sufficiency, \% \\
\hline 2000 & 45.0 & 63.0 \\
\hline 2005 & 53.7 & 60.7 \\
\hline 2010 & 69.5 & 72.2 \\
\hline 2011 & 70.3 & 74.8 \\
\hline 2012 & 75.0 & 75.2 \\
\hline 2013 & 75.9 & 78.3 \\
\hline 2014 & 72.9 & 84.7 \\
\hline 2015 & 72.4 & 89.8 \\
\hline 2016 & 73.0 & 92.0 \\
\hline 2017 & 75.5 & 93.0 \\
\hline 2018 & 75.6 & 95.8 \\
\hline $\begin{array}{l}\text { Recommended norm } \\
\text { of consumption, 2016. }\end{array}$ & 73 & $\mathrm{X}$ \\
\hline Changes (+;-) & 30.6 & 32.8 \\
\hline
\end{tabular}

The research also shows the situation in the meat market to some extent. The increase in meat consumption among population stimulates the demand. However, the demand is limited by buyers' capabilities. The increase in meat production also stimulates the supply of meat products. Nevertheless, the meat market is experiencing some problems, caused by the underdevelopment of regional markets' infrastructure, implying the relationships between all market players starting from production to selling final products [2].

The recommended norms have been revised several times. In 1967 the norm of meat and meat products consumption was $100 \mathrm{~kg}$, in $1990-84 \mathrm{~kg}$, in $2010-75 \mathrm{~kg}$, and since $2016-$ $73 \mathrm{~kg}$. These norms are ever decreasing in Russia due to several factors. In comparison, the EU citizens consume about $90 \mathrm{~kg}$ of meat while an average American, Australian, or Dane consume $110 \mathrm{~kg}$ of meat and meat products. Thus, we can see that the consumption of meat in Russia is lower than in developed countries [10]. Considering the consumption (Table 2) and comparing it with these norms we can see that the shortage is sufficient - $25 \mathrm{~kg}$ per one person/year which approximately equal to 13 broiler chicks or 42 beef or pork steaks.

To determine the level of the country's food security we need to analyse the level of import and export (Table 3). In this case, there are three levels of food security:

1. Optimal (sufficient) - there is enough self-produced food for the internal market (80-85\%), the export is 15-20, the import is $15-20 \%$.

2. Insufficient - the self-produced food in the internal market accounts only for 60 to $80 \%$.

3. Critical - the level of production is so low that there is a dependence on imports. The amount of self-produced food in the internal market, in this case, is near $60 \%$.
TABLE III. THE LEVEL OF MEAT IMPORT AND EXPORT IN RUSSIA FOR 2000-2018

\begin{tabular}{|l|l|l|l|l|}
\hline \multirow{2}{*}{ Years } & \multicolumn{2}{|c|}{ Import } & \multicolumn{2}{c|}{ Export } \\
\cline { 2 - 5 } & $\begin{array}{c}\text { thousand } \\
\text { tonnes }\end{array}$ & $\begin{array}{c}\text { as \% of } \\
\text { production }\end{array}$ & $\begin{array}{c}\text { thousand } \\
\text { tonnes }\end{array}$ & as \% of production \\
\hline 2000 & 2112 & 47.5 & 2.9 & 0.07 \\
\hline 2005 & 3236 & 64.8 & 5 & 0.10 \\
\hline 2010 & 2783 & 38.8 & 21 & 0.29 \\
\hline 2011 & 2574 & 34.2 & 41 & 0.55 \\
\hline 2012 & 2720 & 33.7 & 61 & 0.76 \\
\hline 2013 & 2427 & 28.5 & 66 & 0.77 \\
\hline 2014 & 1710 & 18.9 & 79 & 0.88 \\
\hline 2015 & 1174 & 12.3 & 88 & 0.92 \\
\hline 2016 & 1022 & 10.4 & 166 & 1.68 \\
\hline 2017 & 1015 & 9.8 & 243 & 2.35 \\
\hline 2018 & 756 & 7.1 & 290 & 2.73 \\
\hline Changes (+;-) & -1356 & -40.4 & 287.1 & 2.66 \\
\hline
\end{tabular}

The decreased import $(7.1 \%)$ and increased export $(2.73 \%)$ indicate the optimal or sufficient level of food security in terms of meat products. We should note that the level of imports has decreased by $40.4 \%$. In fact, the country achieved an optimal or sufficient level of food security in terms of meat only in 2015, which is three years after achieving the recommended norm of meat consumption (2012).

Self-sufficiency equal to $95.8 \%$ and $7.1 \%$ of imports indicate a sufficient level of food security, but insufficient production. It is necessary to increase production to form reserves and increase export [9]. These reserves will help to regulate and stabilise the market as well as support prices, etc. The development of agriculture in the situation of international tensions and increased sanctions pressure requires the development and implementation of active measures aimed at increasing the stability of the country's agriculture towards risks and threats [4].

The increase in meat production, i.e. the implementation of an extensive reproduction process is complicated by the production features of this type of goods (working with animals, the influence of climate and nature, shelf life and storage quality, etc.). Also, the extensive reproduction of meat is influenced by macroeconomic risks, the decrease in government support, and investments that lack in this agricultural sector.

To maintain the reproduction process, agricultural organisations need financial, physical, and human resources. The lack of any of these resources impedes reproduction in agriculture [8]. Also, the lack or presence of resources influences the economic conditions and vice versa. Besides the indicated threats there are also risks of sanctions as meat production depends on the supply of fodder, additives, veterinary drugs, high producing animals, genetic material, and equipment for meat processing. This also influences the production volumes of different types of meat. The amount of those types that need more time and money to produce (beef) will continue to decrease, while the volume of more profitable and less time-consuming types of meat production (chicken, turkey, pork, small cattle) will increase. Social risks also influence the volumes of meat production. The decrease in the income of the population will directly lower purchasing power. People will buy cheap types of meat (chicken, turkey, 
pork) which will lead to the disturbance in the structure of meat consumption.

Speaking about Russia in general, we can say that the agricultural sector of the economy is less dependent on imports. However, we cannot exclude such factor as the size of Russia which creates different levels of food security in different regions (donor and recipient regions).

\section{RESULTS}

Providing sufficient and quality food for the population is a paramount task for every state. It is the most important factor ensuring the level of national health. The level and quality of nutrition characterise the extent of social and economic development of the population. They also characterise the health and life expectancy of people by $70 \%$ [5].

The methods used in the research allowed us to determine the type of meat reproduction in the country, assess the level of self-sufficiency and food security.

The analysis showed that meat reproduction in Russia is of extensive type. The annual average growth rate of production for $2000-2018$ is $8.48 \%$.

The indicator of self-sufficiency in terms of meat has been rising for the whole analysed period and achieved $95.8 \%$ in 2018.

The decrease of import (to $7.1 \%$ ) and the increase in export $(2.73 \%)$ indicate an optimal or sufficient level of food security (meat).

\section{CONCLUSION}

Based on the results we conclude that an extensive type of reproduction process has established in Russia. An increased meat production ensures meat self-sufficiency which in turn raises the demand in the meat market. At the same time the import is decreasing, and the level of food security is growing.
The further increase in the level of food security is possible with keeping an extensive type of the reproduction process. This allows increasing both the production and export of meat to other countries, including China.

\section{References}

[1] A.A. Gorbacheva, M.A. Mezinov, "Macroeconomic imperatives for Russian food security", Vest. of Rostov State Univer. of Econ., vol. 6 , no. 4, part 4, pp. 103-105, 2008.

[2] A.I. Mamaeva, G.M. Vinokurov, "Development of the region's pig production market based on the cluster approach", IOP Conf. Ser. Earth and Environmental Sci., vol. 395, p. 012098, April 2019. Retrieved from: https://iopscience.iop.org/article/10.1088/1755-1315/395/1/012098

[3] A.I. Mamaeva, G.M. Vinokurov, "Perspective directions for the development of pig production market in the Irkutsk region", J. of Econ. and Entrepreneurship, vol. 12-1, no. 89, pp. 676-680, 2017.

[4] A.I. Tikhomirov, "Efficiency of import substitution process implementation in the meat and dairy subcomplex of the agricultural sector of the economy", Bull. of Agrar. Sci., vol. 2, no. 83, pp. 138-146, 2020.

[5] B.A. Khakhuk, "The demand for agricultural products in modern conditions", Vest. of Rostov State Univer. of Econ., vol. 7, no. 3, part 3, pp. 97-98, 2009.

[6] K. Borodin, "Economic Access to Food: Factors and Methods of Assessment”, HSE Econ. J., vol. 4, pp. 563-582, 2018

[7] M.F. Tyapkina, V.V. Vrublevskaya, V.I. Samarukha, "Assessment of reproduction of agricultural products", IOP Conf. Ser. Earth and Environmental Sci., vol. 315, 2019 Retrieved from: https://iopscience.iop.org/article/10.1088/1755-1315/315/2/022092/pdf

[8] M.F. Tyapkina, V.V. Vrublevskaya, N.V. Barkhatova, "Resource conditions as the basis for implementing reproduction in agricultural organisations (the example of the Irkutsk region)", Econ. of Agricult. and Proc. Enterprises, vol. 10, pp. 46-52, 2019.

[9] N.Y. Mukhin, “Import Substitution processes in Russian's agroindustrial complex", Russ. Forein Econ. J., vol. 6, pp. 106-117, 2016.

[10] N.Yu. Saybel, N.A. Vidyakina. "The assessment of Russian food security", Vest. of Rostov State Univer. of Econ., vol. 6, no. 4, part 2, pp. 107-109, 2008. 